\title{
The Don Banks Music Box to The Putney: The genesis and development of the VCS3 synthesiser
}

\author{
JAMES GARDNER \\ Private Bag 4800, Christchurch 8140, New Zealand \\ Email: james.gardner@canterbury.ac.nz
}

\begin{abstract}
This article traces the development of the EMS VCS3 synthesiser from the inception of its precursor, the Don Banks Music Box, through its prototype to its commercial release. The nature of the design team and their technical and aesthetic choices are also discussed. The VCS3 is significant in that it was the first commercial European synthesiser and the team that created it - Tristram Cary, David Cockerell and Peter Zinovieff - were key figures in the development of British electronic music. This detailed study of the genesis of the VCS3 and some of the factors that influenced its design touches on many technical and historiographical strands that may be examined in more depth by future scholars.
\end{abstract}

\section{INTRODUCTION}

The VCS $3,{ }^{1}$ launched by Electronic Music Studios (London) Ltd in November 1969 (Cary 1969a; Anonymous 3 1969), was Europe's first commercially produced synthesiser. A compact and modestly priced package, it sported an array of sound-producing and sound-modifying devices that could be freely interconnected, and offered real-time physical interaction via its complement of knobs, button and joystick X-Y controller (Figure 1).

Almost 50 years on, despite being technologically 'obsolete' (a highly contestable term), and readily available in a number of virtual manifestations, the VCS3 has assumed a surprisingly bright glow in the firmament of treasured analogue synthesisers. Original models command astonishingly high prices on eBay. ${ }^{2}$ In this article I shall outline how this device came into being, and some of the factors that went into its design.

The complex interactions between aesthetics, society and technology with respect to electronic musical instruments have been examined over the last 20 years or so by a number of commentators and theorists (e.g. Pinch and Trocco 1996, 2002; Théberge 1997; Patteson 2016), drawing on more generalised models provided

${ }^{1}$ The synthesiser has, through its history, been variously labelled as 'V.C.S. 3', 'VCS-3', 'VCS 3' and 'VCS3'. The last of these is the most common, and the simplest, which is why I have opted for it.

${ }^{2}$ For example, a VCS3 sold for $\$ 18,995$ (c.£13,700) on eBay in March 2016. Another was, as of 8 December 2016, for sale at $£ 10,300$ : www. rlmusic.co.uk/rlm3/ems-ves3-mk1/. by earlier historians of technology (e.g. Ferguson 1974; Pinch and Bijker 1984; von Hippel 1988; Edgerton 2007). These authors rightly assert the non-linearity of technological developments and argue against an overly teleological approach that sees the 'successful', 'stabilised' design (here the VCS3) as the 'inevitable' goal of earlier design work.

Instead of such a 'linear' model, Pinch and Bijker advocate a 'multidirectional view' in which 'the "successful" stages in the development are not the only ones' (1984: 411), and note that it is clear that a historical account founded on the retrospective success of the artefact leaves much untold' (1984: 406).

This article, then, attempts to clarify a small, 'sub-history' within broader field. I do not seek to set out a theoretical model within the Social Construction of Technology. Rather, I want to present merely an enhanced close-up within the larger picture of synthesiser history, while bearing in mind the models and insights provided by the above-mentioned writers, and locate the VCS3's development in the context of the contemporary British electronic music scene in the late 1960s.

One of the difficulties when delving into the history of EMS and its products 40 to 50 years after the fact is the relative paucity of extant contemporary documentation and primary source material. ${ }^{3}$ Most of the office, factory and personal correspondence, internal memoranda and material relating to the development of the instruments has been lost or destroyed. While a fair amount of technical documentation has survived, there are very few records concerning the design process of EMS products. Most discussions of this nature are likely to have taken place informally and orally; consequently, the researcher must draw heavily on the recollections of the surviving parties - whose memories, even with the best of intentions, may be unreliable - and try to divine or reconstruct a plausible and consistent narrative from them. As such, one must acknowledge that there are limits to the accuracy of any account of the development of EMS devices.

${ }^{3}$ Pinch and Trocco encountered similar difficulties in their research on the Moog synthesiser (Pinch and Trocco 1996: 68). 


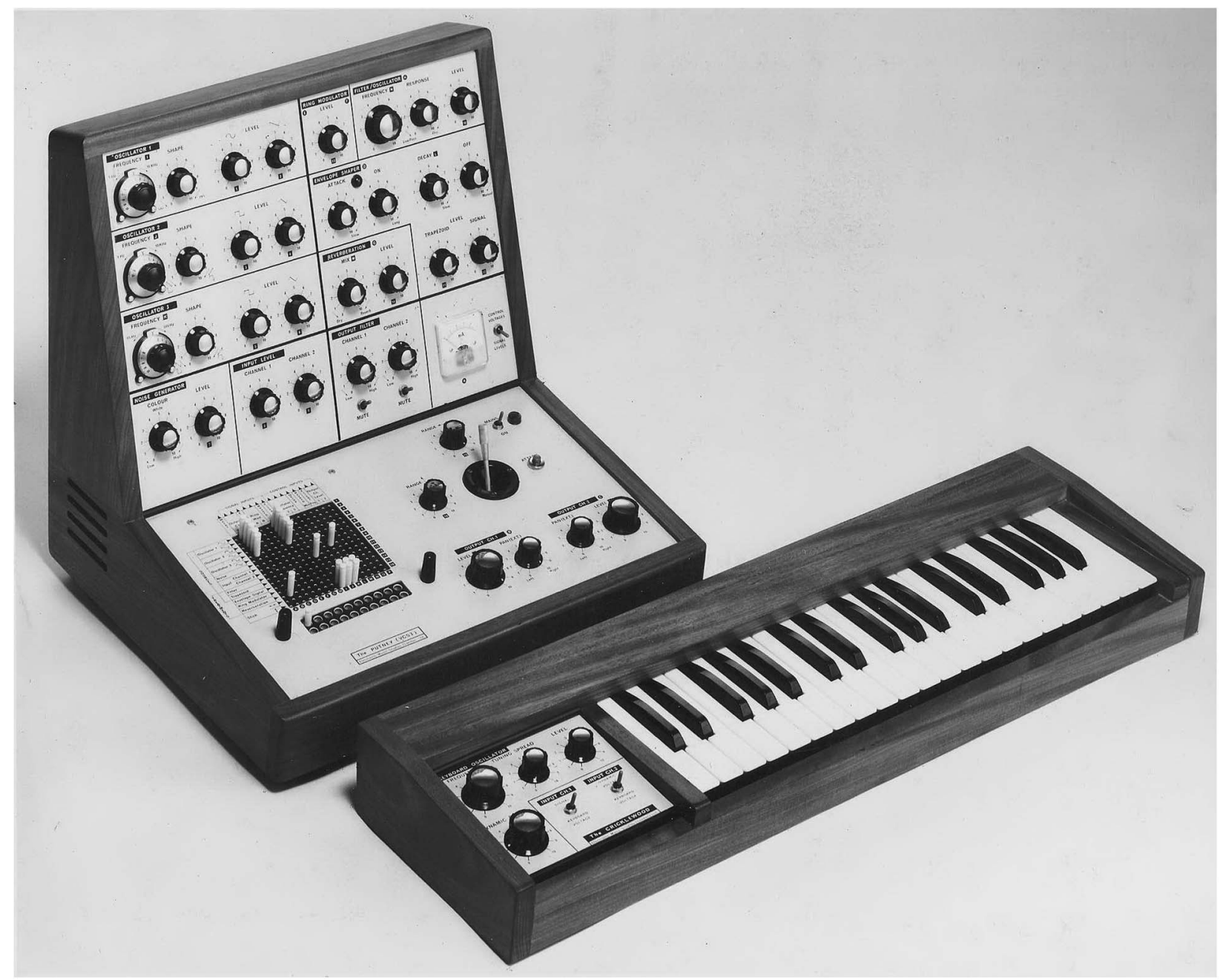

Figure 1. The EMS Putney (VCS3) synthesiser and The Cricklewood keyboard, 1970. Photo courtesy of Robin Wood/EMS Archives.

Overviews of EMS of varying reliability may be found in many publications (e.g. Manning 1985: 235-9; Pinch and Trocco 2002: 276-301; Bate 2006; Gardner 2016; Helliwell 2016: 183-9) and need not be rehearsed here, but it is worth limning the three main players behind the company.

\section{EMS: BACKGROUND AND DRAMATIS PERSONAE}

Peter Zinovieff had set up an electronic music studio in Ebury Street, London by 1963 (Anonymous 1 1963; Oram 1963; Davies 1968: 166-7), and moved his equipment into a purpose-built structure in his garden at 49 Deodar Road, Putney at the end of 1965 (Derbyshire 1965). Zinovieff's interests in controlled randomness, probability and sequencing led him to purchase, in mid-1967, a DEC PDP-8/S computer in order to act as a sort of 'super-sequencer' 4 that

${ }^{4}$ Zinovieff had two generations of 'sequential controllers' before the arrival of the PDP- $8 / \mathrm{S}$. He built his first electromechanical superseded his earlier attempts at automated soundcontrol (Manning 1985: 235; Zinovieff 2010; Dowson 2014).

David Cockerell first entered Zinovieff's orbit around September 1966, building custom hardware for the composer's expanding studio (Cockerell 2014a). Cockerell was (and remains) a brilliant, practical, goalorientated electronics engineer, and unlike Zinovieff, his musical sympathies - both as listener and as amateur player - lay more with contemporary popular music than with the electronic art-music of the time (Cockerell 2000, 2010; Pinch and Trocco 2002: 288).

It is not entirely clear when Tristram Cary was initially contacted by Peter Zinovieff but it appears to have been in late 1966, when Cary was preparing his music for Expo '67 (Cary n.d.; Smart 2009: 80). In this three-person team, Cary functioned as something

\section{(Fnote continued)}

'sequencers' himself in c.1964 using Post Office uniselectors; the second, an electronic 'stochastic sequencer', was built c.1966 by Mark Dowson with help from Humphrey Evans (Zinovieff 2010 , 2016; Dowson 2014; Gardner 2016: 59-60). 
of a middleman between, or as a counterbalance to, Zinovieff and Cockerell. Cary had considerable skills in conventional instrumental composition, and had provided electronic music and sound effects for films and television, including Doctor Who. He had been active in the electronic music field since the late 1940s and had built his own studio in Fressingfield, in Norfolk (Cary 1992: xvi-xxviii; Smart 2009: 30-75).

It would be fair to say that in the EMS team Cary functioned as a bluff, pragmatic foil to the blue-sky thinking of Zinovieff, who was more of an animateur and conceptualist. By early 1969, Zinovieff was imagining a time when the computer would be able to be taught 'the real meaning of words as complicated, say, as "catharsis" and respond to them musically' (Zinovieff 1969: 169). Such flights of fancy were rather removed from the deadlines and briefs that Cary had to meet as a busy freelance composer. But we have to be careful here, and bear in mind that Zinovieff had hand-soldered much of the cabling in his studios and had also, perforce, become a computer programmer (Zinovieff 2010, 2016). It would be misleading to characterise him only as a lofty etiolated spirit, or to caricature him as some sort of aristocratic dilettante, as do Pinch and Trocco (Pinch and Trocco 2002: 281). He got his hands dirty. Conversely, for all of Cary's pragmatism, he did share Zinovieff's essentially modernist view that electronic music was a new medium and consequently deserved 'innovative' instruments rather than 'imitative' ones (Ungeheuer 2008, quoted in Patteson 2016: 164).

Zinovieff and Cary organised the first public concert of exclusively electronic music in London, at the Queen Elizabeth Hall on 15 January 1968. The concert sold out (Crichton 1968) and attracted a good deal of publicity (e.g. Anonymous 2 1968; Cleave 1968), largely due to the onstage presence of Zinovieff's PDP-8/S, which 'performed' his Partita for Unattended Computer in real time (e.g. Sadie 1968; Various Authors 1968).

By mid-1968, Zinovieff's Putney studio had hosted an SPNM weekend for composers (Gilbert 1968), appeared in Hugh Davies's International Electronic Music Catalog (Davies 1968: 166-7) and was gaining recognition. But it was expensive to maintain and expand, and despite Zinovieff's access to considerable wealth, an additional source of revenue was necessary.

Cockerell recalls a conversation with Zinovieff in July 1968 about establishing some kind of company to sell electronic music hardware (Cockerell 2014a). The following month The Guardian published an article by Cary in which he argued for a National Centre for Electronic Music. It included this intriguing paragraph:

Two manufacturers in America, Moog of New York and Buchla of San Francisco, do market electronic music devices in modular form[.] [...] But the prices are high even by US standards [...] and allowing for the devalued pound and other burdens on the importer they are quite out of the question for most British customers. In any case we have our own brilliant designers who would produce better and cheaper systems if they turned their attention to it. (Cary 1968)

I contend that when Cary refers to 'our own brilliant designers', he actually meant David Cockerell, and that the task of producing 'better and cheaper systems' was one to which Cary and Zinovieff were already turning their attention in principle, if not in practice.

By August 1968, then, the three main characters, or reagents, of EMS were in place, and it seems likely that sooner or later they would have produced some kind of commercially available electronic music equipment; partly to fill the obvious gap in the market that Cary had identified, and partly to finance the Putney studio. But in the autumn of that year, a catalyst arrived to speed up the process: Australian composer Don Banks.

Banks had been in the UK since 1950 (Hair 2007: 7, 19). Like Tristram Cary, he was by necessity a pragmatic, jobbing composer who did much film and TV work, as well as what Cary would call 'concert music'; the two composers' paths had already crossed thanks to their movie assignments. Banks's interest in electronic music had been piqued by a 1966 Paris performance of Mario Davidovsky's Synchronism 2 for four live performers and pre-recorded sounds (Banks 1970b), but he had no studio access, nor enough money to purchase any suitable electronic equipment of his own (Banks 1972, 1977).

\section{THE DON BANKS MUSIC BOX}

The basic story of the Don Banks Music Box has been recounted by Cary (and others) in print and in interviews in various media, with minor variations (e.g. Cary 1992: xxv, 2006; Bate 2006). However, the nearest to a contemporary account that I have come across so far is Banks's own, from 1972. His story of the instrument's origin runs like this:

when spending an evening with Peter Zinovieff I complained bitterly about the lack of facilities for composers to learn the language of electronic music. Peter, as generous as ever, said he would ask David to design a kind of instrument which would incorporate a number of facilities which one would need to know about in the production and treatment of sound. 3 Weeks [sic] later I had a grey box [...] which incorporated all the basic principles. At the time it was known as the 'Don Banks Music Box'. Actually three were built and are still in use. (Banks 1972)

There are two things to note here. First, Banks says 'At the time it was known as the "Don Banks Music Box"" (hereafter DBMB). I shall return to this point later. Second, he mentions that three units were constructed. 


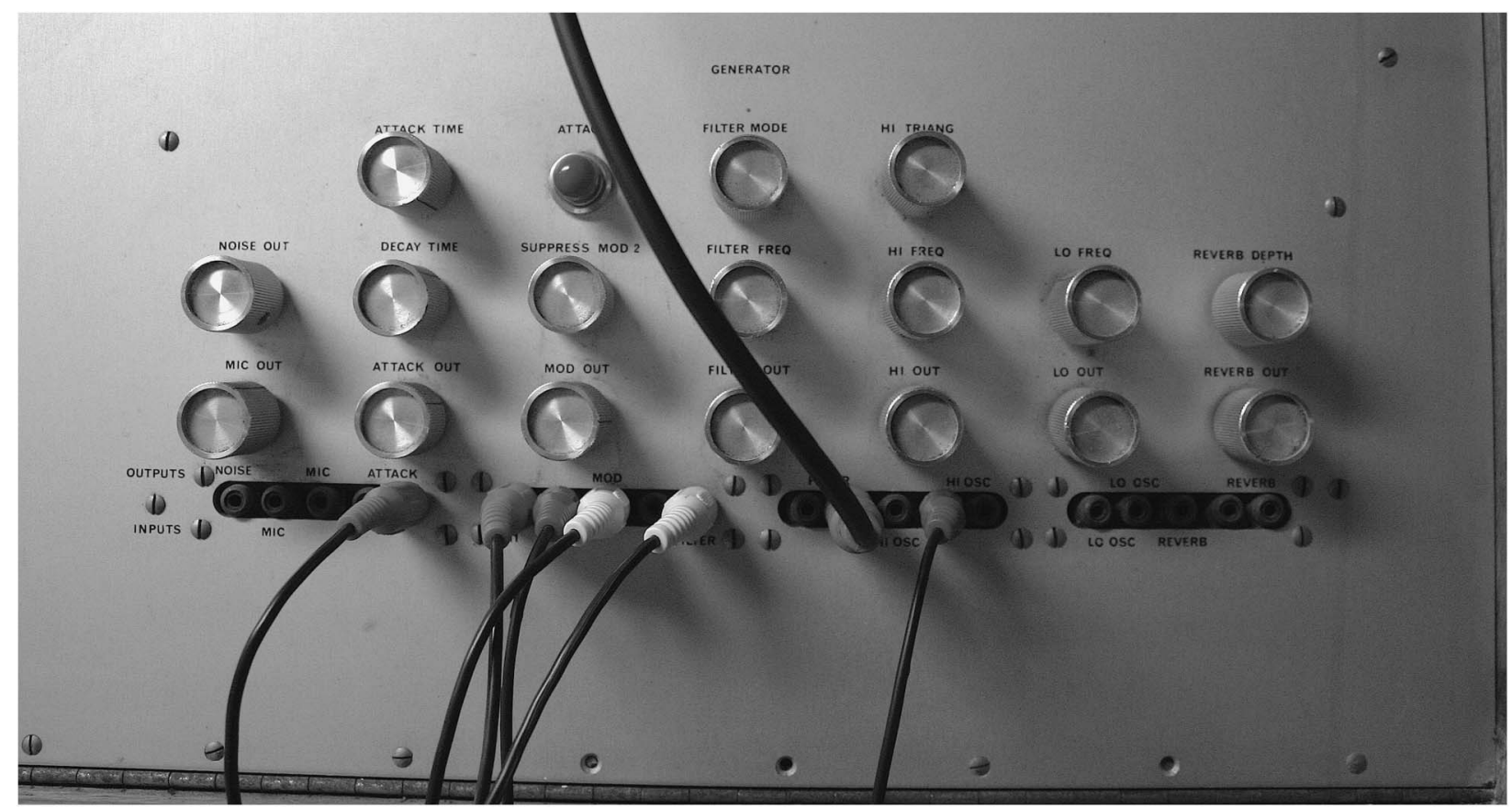

Figure 2. Keith Humble's synthesiser (c.1968) built into a larger unit by Graham Thirkell and now in the collection of MESS Ltd, Melbourne. Photo: James Gardner.

The other two units eventually went to Lawrence Casserley, then Cary's student at the Royal College of Music, and Banks's Australian friend, the composer Keith Humble (Figure 2). ${ }^{5}$

It is also worth noting that the DBMB's design specification did not come from Banks himself. According to his 1972 account, he deferred to Zinovieff and Cockerell as to 'which facilities [...] one would need to know about' - note the imperative. It could be argued, then, that one of the main determinants of the DBMB design was Zinovieff and Cockerell's opinion of what a composer ought to find useful.

Another determinant, of course, was Banks's budget. Tristram Cary's accounts of the genesis of the DBMB are similar to those of Banks, but Cary consistently claims that Banks came to 'us' - rather than Zinovieff alone - and that his price limit was $£ 50$, rather than the $£ 100$ that Banks once recalled (Banks 1977).

Cockerell's account suggests the DBMB was made partly to assess the appetite among musicians for such a device: 'I just put together various bits and pieces that I'd previously built for Peter and put them in a selfcontained box to see if musicians would find any use for it' (Cockerell 2010). It would be a stretch to see this as 'market research' but it does hint that Zinovieff was

${ }^{5}$ Don Banks's original unit is at the Powerhouse Museum, Sydney (Powerhouse Museum n.d.). Lawrence Casserley's is in the Gemeentemuseum in The Hague (Blommers 2001). Keith Humble's device, incorporated by Graham Thirkell into a larger unit that also includes an early EMS twin ring modulator, is in the collection of MESS (Melbourne Electronic Sound Studio Ltd). testing the water for a commercial product at this early stage.

In later interviews and articles, Cary asserted that the DBMB was called the VCS-1, positioning it clearly as the first device in a consciously numbered series culminating in the VCS3. In this sense, Cary could be seen to be guilty of the 'linear' approach disparaged by, inter alios, Pinch and Bijker. I have, however, found no use of the term 'VCS-1' that pre-dates the release of the VCS3, and I would argue that the 'VCS-1' name for the DBMB was applied only retrospectively; well after the VCS3 name had been adopted in the second half of 1969. The earliest use of the term 'VCS-1' I have found thus far is in a letter from Banks to the New Zealand composer Douglas Lilburn, dated 30 August 1970 (Banks 1970a).

Lawrence Casserley's unit does not actually say 'VCS-1' anywhere. Rather, it is labelled 'Electronic Music Studios Sound Synthesizer' in Letraset. Casserley is adamant that the label was already on the device when he picked it up in spring 1969 from Delia Derbyshire, to whom it was on loan (Casserley 2015a). At the time, it had been in the Camden studio of Kaleidophon - the company name under which Derbyshire, Brian Hodgson and David Vorhaus were then working. The circulation of this particular DBMB can be seen as a kind of beta-testing on the part of EMS by potentially interested colleagues or acquaintances. None of these, it should be noted, was directly active in the popular music field, though Derbyshire and Hodgson did associate with figures from the contemporary underground and countercultural art 
scenes. Asked about his first encounters with the DBMB and VCS3, Hodgson reflected on the loose professional and social networks of the time:

I seem to remember Peter mentioning Don Banks and things like that. One was just on the scene - it's hard to explain the complete informality of the way life was in those days, in the ' 60 s. Nowadays everything's cut and dried. In those days we were all wafting around. [...] It was much more informal - a whole lot of relationships were. [...] Tristram was around quite a lot, and he was a good friend of Delia and me. And so in a way a lot of the communications that went on with EMS would go through Tristram. (Hodgson 2014)

The informal knowledge-sharing that was common among electronic music practitioners of the time is also illustrated by the handwritten instructions and notes that Banks prepared for Keith Humble to help him get to grips with his DBMB (Banks 1969) - notes that in turn amplify Cockerell's original instructions to Banks (Cockerell 1968).

If we regard the DBMB as a convenient and costeffective collection of devices that David Cockerell assembled for Banks, we have to ask how this specific collection was arrived at. A definitive answer to that question is impossible at this distance, but it seems likely that Zinovieff and (probably) Cary drew on their combined experience as electronic music practitioners and conferred about the most useful devices. This, of course begs the question: useful for what? The point here is that the criteria behind this choice are not simply technical or pragmatic, but also aesthetic. As I noted earlier, we could characterise Cary and Zinovieff's standpoint with regard to electronic music as post-war modernist, seeking to create a new music from the raw materials of sound, freed from the constraints of acoustic instruments, and thus the technological design of the DBMB is closely allied with these aesthetic, or even ideological, aims.

What features did they choose for the DBMB?

\section{THE DON BANKS MUSIC BOX: BASIC FEATURES}

1. White Noise Generator.

2. Mic. pre-amp.

3. Envelope Generator (with attack and decay controls only).

4. High Frequency Oscillator (sawtooth/triangle with variable waveshape) with a quoted basic frequency range of $1 \mathrm{~Hz}$ to $2 \mathrm{kHz}$, but greater via voltagecontrol.

5. Low Frequency Oscillator: falling sawtooth wave only, $25-300 \mathrm{~Hz}$ range.

6. Filter with variable $\mathrm{Q}$, capable of self-oscillation. Cutoff not voltage-controllable.
7. Ring Modulator/Voltage Controlled Amplifier.

8. Reverb.

It is worth noting that the DBMB does not offer an easy way of producing sequences of specific discrete pitches from its front panel controls, or straightforward control of pitch from an external keyboard. This is hardly hardly surprising, given Banks's needs and Cary and Zinovieff's aims. The patching, by means of RCA connectors, is reasonably flexible, allowing devices to be connected in many different ways; there is no normalised signal or control path. The DBMB is a compact, self-contained device designed for soundgeneration and sound-processing, offering a lot of 'bang for the buck'. Described thus, it may easily be viewed as a precursor of the VCS3, though its human interface is crude: just rotary knobs and one attackinitiation button. But it would be misleading to describe the DBMB as a VCS3 'prototype': there seems to be no evidence, at its design stage, that there was a vision of a more sophisticated commercial synthesiser for which the DBMB was a portent.

From the outset, then, the DBMB was designed with signal processing and synthetic tone generation in mind. This ability to process external sounds as well as to generate them internally was carried into the design of the VCS3.

Banks was clearly delighted with his new synthesiser: 'Thank heaven for the age of miniaturisation' he enthused, 'because this was small enough for me to take to bed with headphones, and to start to explore a new world of sound' (Banks 1970b). Indeed, on a trip to his native Australia in April $1970,{ }^{6}$ the Sydney Morning Herald reported that:

One advantage of electronic music is that you can compose sitting up in your bed, with the aid of your Voltage Controlled Synthesiser. The V.C.S. (also known as the Don Banks Music Box) produces [... various waveforms ...] Australian composer Don Banks had his electronic synthesiser specially built for him, and takes it with him everywhere he goes [...] At home in Purley, near London, he takes it to bed to work out sound combinations, but uses headphones to placate his wife, who objects to electronic music at bedtime. (Jones 1970)

Banks did not see his synthesiser as the VCS3's linear forebear. When asked whether the DBMB was 'the beginning of the VCS3', he answered:

Well, yes, in a very funny way I expect it could be seen as that. But it was only because I was putting the pressure on Zinovieff that ... you know, there were a whole number of independent composers who needed help, who needed to be able to work at home. And I expect probably from that that [the VCS3] did start. But that was not originally ... not

${ }^{6}$ Banks did own a VCS3 by this time - he had taken delivery of one in January that year - but he obviously relished the portability of the DBMB. 
in Zinovieff's mind. I think it just happened that he saw there was a demand. (Banks 1977; my italics)

Banks's assertion that numerous composers had been in the same position as him is worthy of note: there was a perceived need, and market, for such a device. Not only that, Banks credited the later VCS3 with empowering the previously disenfranchised 'independent composer': 'we were able as independent composers at the time to make a start at [electronic music]' (Banks 1977).

The DBMB, while useful, was not, in Cary's opinion, sufficiently well-specified to be a viable commercial product, but 'it spurred us on to dream up a more sophisticated package with features we couldn't put into Don's little grey box' (Cary 2000), a package that 'would appeal not only to composers but also to schools [...] [a] very good teaching instrument for acoustics and so forth' (Cary 2003).

The positive reception of the DBMB, then, led the team to consciously address in the subsequent 'package' not only what they perceived as the needs of the art music composer, but also to position the new device so it might appeal to a wider market.

\section{THE EMS ELECTRONIC MUSIC STUDIO MK I}

Following their success with the January 1968 concert of electronic music at the Queen Elizabeth Hall, Zinovieff and Cary organised a second in February 1969. The elaborate foil-fronted programme booklet for that concert includes many essays and interviews, as well as about 20 pages that would now be thought of as an 'advertorial' for EMS (Various Authors 1969) (Figure 3). Somewhat prematurely, EMS was by now presenting itself as a viable company ${ }^{7}$ offering no less than three products, described in some detail in this booklet. The first two - the Twin Ring Modulator, and the Dynamic Filter - were hand-made in very small quantities. But it is the third product that is of most interest for the VCS3 story. This is the 'EMS Electronic Music Studio Mk I', with a quoted price of $£ 260$. Its specifications, as detailed in the programme booklet, indicate a rather more sophisticated unit than the DBMB.

Considered as the precursor of the VCS3, there are a few notable things about the Studio Mk I's advertised features. It has two oscillators, which both have the same (wide) frequency range and provide 'various waveforms'. There is a VCF with voltage-controlled centre frequency and, unusually, voltage-controlled bandwidth - just like EMS's contemporary Dynamic Filter. The description of the envelope generator is very similar to that of the VCS3 (attack, on, decay, off,

${ }^{7}$ EMS was incorporated as a limited company on 25 July 1969 . The Memorandum and Articles of Association are in the EMS archives in Cornwall. with optional automatic retriggering), and therefore a significant advance on the DBMB, while the noise, ring modulator and reverb are similar to those of the earlier device. The instrument would appear, like the VCS3, to be designed as a 'stereo' (more accurately, twochannel) device - the DBMB was mono.

More significant, perhaps, is the first mention of the 'Pin Panel Matrix' for patching. This would be one of the VCS3's most characteristic features and, indeed, selling points. Like the DBMB, Moog and Buchla instruments employed patch cords for interconnecting their modules. Complex patches would result in a tangled thicket of cables, but the matrix patching was tidier, dispensing with such 'knitting', and had the added advantage - by doing away with jack sockets of enabling a much more compact panel design.

Are there any surviving examples of the EMS Electronic Music Studio Mk I, the 'VCS2'? As so often with early descriptions of EMS devices, this enticingly detailed text is best described as somewhat 'aspirational'. In later life, Cary seemed unsure about the putative device. In one account he says 'I'm not sure what the VCS2 was like, or even if there was one' (Cary n.d.), and in another 'The VCS 2 was abortive and intermediate' (Cary 2000). David Cockerell has, however, confirmed that no functioning device matching the description of the Studio Mk I was ever actually built (Cockerell 2014b). It seems clear, then, that if anything can be called the 'VCS2' - the 'missing link' between the DBMB and the VCS3 - this piece of vapourware is it. Whether or not the Studio Mk I was actually constructed, the advertised 'product' suggests a concerted effort on the part of the team from late 1968 into 1969 to create a marketable product that was significantly more advanced than the DBMB. The specification here is perhaps best viewed as a snapshot of the point the design process had reached when the programme booklet went to print. It was not - to use Pinch and Bijker's terms - a 'closed' or 'stabilised' artefact.

\section{TRISTRAM CARY'S VCS3 PROTOTYPE}

Although the Studio Mk I was not actually made, its specification built on that of the DBMB and shows the direction Cary, Cockerell and Zinovieff were taking as they worked to design a viable commercial product during the early months of 1969 . According to Cary, at least some of the discussions took place at the Cedar Tree Pub in Putney Bridge Road and it was reputedly there that the distinctive L-shaped 'baby desk' form of the VCS3 emerged (Cary 2000, 2003, n.d.). There are conflicting reports on just whose idea this shape was. According to Zinovieff (2000), Cary 'came up with it and we liked it. [...] he found it easy to work with, and he thought this was the right way of having 


\title{
ELECTRONIC MUSIC STUDIOS 49 DEDDAR RDAD LONDON S.W.15. 01-874-2363
}

\author{
THE EMS ELECTRONIC STUDIO MARK I \\ $\operatorname{cosT} £ 260$ \\ This self contained studio allows anyone to make electronic sounds and \\ manipulations that can normally only be created in expensive and large \\ studios. \\ The unit is contained in a metal box $10^{\prime \prime} \times 19^{\prime \prime} \times 5^{\prime \prime}$ and is self powered. \\ Broadcast standards are maintained within this small size by utilising \\ the latest solid state devices and integrated circuits. The unit also \\ contains two power amplifiers which may be connected directly to loud- \\ speakers. \\ The studio can be used either in conjunction with a tape recorder for \\ tape manipulation or else with microphones for real time distortion \\ and treatment of instrumental or other concrete sounds. \\ Sequences of sounds can be arranged from an external sequencer or \\ keyboard as all the pitch, timbre and loudness devices are voltage \\ controlled. \\ The unit contains the foslowing electronic devices: \\ 2 Voltage-controlled oscillators \\ These have a range of .1hz ( 10 seconds) to $20 \mathrm{~K} \mathrm{hz}$ with a frequency \\ voltage relationship that is logarithmic with the result that voltage \\ increments give a sensible musical pitch increment that is similar over \\ the entire audio range. Various waveforms are available.
}

Figure 3. The first page of the description of the 'EMS Electronic Studio MkI' from the QEH concert programme, 10 February 1969. Author's collection.

an angle, so you could sit in front of it'. Cockerell (2000) thought the 'desk' was 'a very good shape, those two panels that face you in that way. I think [Cary] saw it mostly as a teaching machine - demonstrations and teaching'.

It would seem, then, that Cary's notion of sitting at the VCS3, as if at a school desk, determined the overall shape of the VCS3, and he hand-built the wooden case in this form for the prototype (Cary n.d.; Cockerell 2010; Zinovieff 2010), delivered to Cockerell in spring 1969. Contemporary documents also suggest it was Cary who came up with the initial layout of the controls, ${ }^{8}$ while Cockerell was responsible for the circuit design and construction of the electronics.

In the interests of keeping the costs of the VCS3 as low as possible, Cockerell's circuit designs were again simple and expedient, and largely based on public domain circuits. For the filter he adapted Bob Moog's 'transistor ladder' design using diodes instead of transistors - diodes were much cheaper (Cockerell 2000, 2010). The slow-motion Vernier oscillator frequency

${ }^{8}$ The panel layout drawings for the VCS3 prototype are clearly in Cary's hand, and acknowledged as such by Cockerell (Cockerell 2015). The actual panel labelling on the prototype, however, is probably Cockerell's. dials and matrix patch board ${ }^{9}$ were initially sourced from the electronic surplus shops in Lisle Street (Cockerell 2000, 2016), and it was also Cockerell's idea to include a joystick in order to control two parameters at once (Cockerell 2000).

Yet the specifics of Cockerell's oscillator design decisions were also informed by the musical aesthetics of Cary and Zinovieff. Neither composer was overly concerned in their electronic music with stable, equaltempered pitches. Despite the first brochure's claim of 'drift-free performance' (Cary 1969a), Cockerell's initial oscillator designs did not prioritise frequency stability, much to the chagrin of later melodically orientated owners.

The 'stable' design of the VCS3 incorporated the following devices:

1. Three oscillators, two designed primarily to operate in the audio frequency range and a third intended as a sub-audio control (though all three had a wide frequency range), all offering continuously variable waveforms.

\footnotetext{
${ }^{9}$ Towards the end of 1968 a large patch matrix had been introduced to connect devices in Zinovieff's studio (Cockerell 2014a); this prompted the use of a matrix on the smaller machine.
} 
2. A noise generator with integral filtering for different colours of noise.

3. A filter with voltage-controlled cutoff frequency, capable of self-oscillation.

4. An envelope/trapezoid generator with attack, on, decay and off controls, with voltage-controlled decay.

5. A ring modulator.

6. A spring reverb unit, with voltage-controlled wet/ dry mix.

7. Two input amplifiers/channels (for processing external signals).

8. Two output channels.

9. Two built-in loudspeakers.

As mentioned earlier, the VCS3 also had a push-button for triggering the envelope generator, a joystick, and a meter for displaying signal or control voltages.

As such the VCS3 specification represented a consolidation and refinement of that given for the 'Studio Mk I', rather than a huge advance on it. There is simply insufficient documentation to account for the changes, but it is plausible that the practicalities of making all the important signal and control voltages accessible via the 16x16-hole matrix might explain, for instance, the simplified filter design (no voltagecontrolled bandwidth), the reduced parameters of which would free up space on the matrix for, say, a valuable additional oscillator. ${ }^{10}$ The similarity of the VCS3 and 'Studio Mk I' specification does suggest that the bulk of the design work took place during the winter of 1968-69.

According to Tristram Cary, many visiting composers were shown, or lent, the prototype VCS3, as they had the DBMB (Cary 2003). Again, this was an informal beta-testing, among the small circle of Cary and Zinovieff's acquaintances in the world of art music (Cary n.d.). At this early stage, there seems to have been no attempt to pitch the prototype to anyone from the world of popular music.

\section{THE FIRST VCS3 LEAFLET, AND VCS3 PRODUCTION}

Cary's prototype has a frustratingly smudged marker pen label that appears to say 'E.M.S. Studio [Mk..]' but by August 1969 the name VCS3 - ostensibly standing for Voltage-Controlled Studio [Mark] 3 - had certainly been adopted (Cary 1969b), probably at Cary's behest. He thought it 'had a good ring about it' (Cary n.d.), but the numbering also retrospectively formalises and linearises what was, in reality, a much more haphazard development process.

\footnotetext{
${ }^{10}$ According to Lawrence Casserley, '[T] he original plan had a larger pin matrix, but they got a very good deal on a batch of $16 \times 16$, so some planned features were omitted or altered' (Casserley 2015b).
}

The rough-and-ready layout of Cary's vernal prototype was neatened, and its design formalised, into the one-off pre-production unit ${ }^{11}$ pictured on the cover of the first VCS3 brochure, dated November 1969. The 'productionisation' process of the synthesiser was, however, already under way by July 1969, and this was undertaken by the brothers Gerry and Brian Rodgers, soon to operate as EMS (Bournemouth) and who would subsequently establish a small factory for VCS3 production in Wareham, Dorset.

Tristram Cary wrote the text of the first VCS3 brochure and it is clear from the cover photo at least that the instrument was being pitched squarely at the 'serious composer'. Its iconography is clear: horn-rimmed glasses, a pen - and the VCS3 itself - rest on an opened book about computer music, showing a notated musical example. To be fair, Cary's text does attempt to appeal to a wide range of potential users, noting five distinct types of application, ${ }^{12}$ and emphasising its design credentials and cost effectiveness: 'The VCS3 Electronic Music Studio is the result of two years collaboration between musicians and electronic engineers and embodies circuitry which cannot be equaled by instruments costing four or five times its price' (Cary 1969a).

Cary also draws attention to a possible playing mode: 'The joystick is placed so that it and the [attack] button can both be operated by the right hand, leaving the other free for altering knobs or matrix plugging' (ibid.). The VCS3 was much more playable than the DBMB and much thought (and beta-testing feedback) had clearly gone into its ergonomics and interface. This, along with its ability to process external sources, and low cost, contributed to its rapid adoption by live electronics groups such as Intermodulation and Gentle Fire. ${ }^{13}$ Indeed, by February 1971, the use of the VCS3 by such groups was sufficiently ubiquitous for Michael Nyman - an early adopter himself - to quip about 'the regulation VCS 3' when reviewing Gentle Fire's Elizabeth Hall debut for the The Musical Times (Nyman 1971).

Although the leaflet is dated November 1969, the first VCS3s were delivered to customers in December. The very earliest VCS3s seem to have been priced at $£ 285$, but within weeks $£ 330$ was established as the first settled price. ${ }^{14}$ While this represented a substantial outlay - over ten times the average weekly wage (Clark 2016) - the VCS3 still cost less than one-fifth of a

\footnotetext{
${ }^{11}$ This unit, now in the collection of the National Music Centre, Calgary, was essentially the same as the first production units, though it lacked a shape control for oscillator 1 .

${ }^{12} 1$. As a complete unit in itself. 2. As an electronic music studio 3. As a live performance instrument. 4. As a sound effects generator. 5. As a teaching aid.

${ }^{13}$ But not without ambivalence. Gentle Fire's Hugh Davies wrote: 'We all had a love/hate relationship with the VCS3 synthesizer' (Davies 2001: 57).

${ }^{14}$ This assertion is based on an examination of the extant stock cards in the EMS archives.
} 
similarly featured Moog. Their least expensive off-theshelf model at the time, the Moog Ic, was $\$ 4,305$ - then around $£ 1,800$ (R. A. Moog Inc. 1969). For a short time at least, the VCS3 had no real competition in the $\mathrm{UK}$ and in continental Europe.

Somewhat surprisingly, Cary seems to have been aware at the time that EMS's window of advantage would not stay open for long. According to an interview in January 1970, he expressed the prescient hope that the VCS3 could 'be developed, patented and sold to the American market before the Japanese catch up' (Abbot 1970). While the evidence is slim, it would appear that the pressure to take advantage of this short-lived business opportunity was another factor in getting the VCS3 into production within a few months of its design.

\section{THE KEYBOARD PROBLEM}

EMS did not release a keyboard for the VCS3 until about June $1970 .{ }^{15}$ As a result, it has often been assumed that the keyboard was merely an afterthought, ${ }^{16}$ and not part of the initial design. The truth is more complicated, however. The final sentence on the first leaflet reads: 'EMS will shortly announce a range of peripheral equipment including a sequencer keyboard ${ }^{17}$ which it will be possible to add to an existing VCS 3 by simply plugging it in, a special socket having been provided for this purpose' (Cary 1969a). This would indicate that a keyboard was considered from the outset (albeit as an optional peripheral) and an examination of the preproduction unit confirms this - it has an explicitly labelled 'keyboard' socket on the back.

In fact, Cary and Cockerell did communicate about a keyboard designed specifically for the VCS3 as early as August 1969, some three months before the synthesiser's official launch. I will not attempt a detailed technical discussion here, but it was conceptually a non-standard keyboard - more of a flexible 'alternate controller'(Cary 1969b).

Yoking an equal-tempered keyboard to a synthesiser was anathema to Cary, who would later reflect that 'The whole thing became rather debased I think in the ' 60 s when keyboards came in. I was quite shocked [...] because the whole thing about electronic music for me was you were getting away from keyboards, one thing you wanted to avoid in electronic music was 12 notes to the octave' (Cary 2006). Again, Cary and

\footnotetext{
${ }^{15}$ Date is based on an examination of stock cards, supported by other contemporary documents.

${ }^{16}$ Indeed, Cockerell himself has contributed to this confusion: 'Peter and Tristram weren't really that much interested in well-tempered music. And I thought it should have had a keyboard from the start. We added one on as an afterthought' (Cockerell 2010). The historical record does not, however, entirely support Cockerell's recollections. ${ }^{17}$ Cockerell was in fact working on digital sequencer around this time (Cockerell 2015), but the first EMS sequencer keyboard would not appear until spring 1971.
}

Zinovieff's aesthetic stance would have a strong effect on the development of the instrument.

One should not underestimate the influence of the salesman, however. Paul Théberge (1997: 54) quotes von Hippel (1988: 54): 'Any party that stands to benefit from [a technical] innovation - as user, manufacturer, supplier, distributor [...] can be regarded a potential source of innovation.' EMS's first American agent, Alfred Mayer, pushed for the production of a keyboard when he took on the US distribution in very early 1970 (Cockerell 2015), but it took EMS many months to get such a unit designed and manufactured. When it finally did appear, the DK-1 keyboard was playable as a conventional equal-tempered keyboard, but it retained the scalability of the experimental model, allowing the pitch range of the keyboard to be varied to produce micro- and macrotonal intervals. Unusually for the time, the keyboard was also velocitysensitive, producing a voltage that was proportional to strike force. This voltage would 'normally' control dynamics, but could be assigned to any voltagecontrollable parameter.

Mayer was also responsible for insisting on the alternative names for the VCS3 - The Putney ${ }^{18}$ - and the DK-1 keyboard - The Cricklewood. The received wisdom was that for 'technical' products, the Americans preferred names; the British, numbers (Cary 2000, 2003, n.d.). One can only assume those names sounded more exotic to Mayer's ears than they did to those of Londoners.

Much can be made of the VCS3's lack of keyboard, particularly to highlight Cary and Zinovieff's disdain, but it is worth remembering that none of the few commercially available synthesisers at the time had integrated keyboards. The EML ElectroComp 200, made specifically for educational use, had none. Buchla, meanwhile, offered the 'touch-controlled voltage sources' instead of a conventional keyboard (Pinch and Trocco 2002: 42-5). Moog did, of course, sell a conventional keyboard (always pictured with the synthesiser in brochures), but it was still a separate unit. The keyboard became an integral part of the synthesiser only with the advent of the Minimoog in October 1970 (ibid.: 232).

\section{TOWARDS A CONCLUSION}

In this article I have shown that the development of an electronic musical instrument, even one with such a

\footnotetext{
${ }^{18}$ There is a common misconception that the VCS3 was actually rebadged as 'The Putney' in the USA but this was not the case. Probably in the interests of economy, most of the production run of the VCS3 Mk1 carried both names, but the instrument was promoted as 'The Putney' in the US and the 'VCS3' in the UK. After the introduction of the 'Synthi' brand for the EMS product range in spring 1971 the 'Putney' and 'Cricklewood' names were dropped - as was Mayer as US agent.
} 
short gestation, is multiply determined and non-linear, based on the contingent and sometimes capricious decisions of a number of agencies - or 'relevant social groups' as Pinch and Bijker (1984: 414) might put it of which the three-man design team was just one. In drilling down via a close examination of extant contemporary materials and later interviews I have given a more detailed and plausible account of how and why the VCS3 emerged as a 'stabilised artefact' in this specific form than earlier histories. ${ }^{19}$

I must acknowledge that there is further work to be done, however, and that the VCS3 is only provisionally 'complete'. As Théberge (1997: 50) notes: 'The design process alone does not determine how an instrument comes to embody, limit or exhaust its musical potential. Indeed an instrument is never really completed at the stage design and manufacture at all; it is only made "complete" through its use.' I have made scant mention of the way in which the VCS3 has actually been used in music, and sound design; suffice to say for the present that its use - and therefore meaning - broadened rapidly from the user base originally envisaged by Cary and Zinovieff, as the synthesiser became associated more and more with popular musics between 1969 and 1973. Over the last two decades new meanings have been conferred on the VCS3 by its positioning in both the 'vintage' synthesiser pantheon and its place in the wider world of virtual, and new analogue modular, synthesisers.

I would also contend that meaning, pace Théberge, is also conferred by the affect that an instrument evokes in its users (or even viewers), an affect that transcends dry, functional descriptions of components and technological features. It is beyond the scope of this article to try to account for the VCS3's numinosity or to explain how and why it has become such a technological object of desire, or fetish - though I may attempt that elsewhere. I hope, at least, that I have made a case that the VCS3 has a cultural import beyond the 'electroacoustic community' and as such is worthy of deeper study. As for my speculations on the importance of affect on the user of musical technology - here the VCS3 - I leave the reader with a starting point: an early American review that hints at its haecceity:

[T] his 25-pound console offers [...] a nonformidable array of dials. [...] In its presence, even an apprehensive music teacher could feel safe. The plugging panel, with its tiny plastic-topped connectors, was no more threatening than,

${ }^{19}$ It could be argued that the VCS3 was not the 'stable' and 'closed' artefact resulting from this design 'vector' and in fact the stabilised form was the EMS Synthi A, officially launched in May 1971. Functionally almost identical to the VCS3, it was designed by Brian Rodgers to fit in a Spartanite attaché case, with the two panels of the VCS3 condensed into one face. It was much more compact and 'roadworthy' than the wood-panelled VCS3, and in some senses an 'advance' on the earlier design. The Synthi A and VCS3 have co-existed in the EMS range until the present day. say, a pocket chess set. [...] There are a lot of knobs, to be sure, and a handful of unfamiliar labels. But the console is so small and so innocent looking. One instinctively trusts it. (Willis 1970)

\section{Acknowledgements}

I should like to thank Lawrence Casserley, David Cockerell, Les Craythorn, Claire Harris, Brian Hodgson, Fiona McAlpine, James Mooney, Trevor Pinch, Nicole Saintilan, Gabriella Smart, Robin Wood and Peter Zinovieff for making available - or alerting me to - material used in the preparation of this article. Thanks are also due to Robin Fox and Byron Scullin of MESS Ltd, Melbourne for allowing me hands-on access to Keith Humble's DBMB.

\section{REFERENCES}

Abbot, B. 1970. Radar Led Him to His Music. Diss Express, 16 January.

Anonymous 1. 1963. This Kind of Music Gets a Family Moving. Daily Express, 14 November.

Anonymous 2. 1968. Virtuoso PDP 8/S Getting an Attack of Concert Nerves. The Sun, 16 January.

Anonymous 3. 1969. British Studio Makes Moog Equivalent. Music Business Weekly, 22 November, 7.

Banks, D. 1969. Notes for Keith Humble on use of 'E.M.S. Synthesizer Model A'. Papers of Keith Humble, NLA series 14, Item 7, National Library of Australia, Canberra.

Banks, D. 1970a. Letter to Douglas Lilburn, 30 August 1970. Folder 2, Box 7 (VEMS00046) J. C. Beaglehole Room/ Tānga Puiaki, Victoria University of Wellington.

Banks, D. 1970b. Electronic Music. The Sounds of Music. BBC Radio 3 Lecture, broadcast 26 November 1970. MS6830, Manuscript Box 32, Folder 239. The Don Banks Collection, National Library of Australia, Canberra.

Banks, D. 1972. Transcript of Synchronos '72 Interview. MS6830, Folio Box 3, Plastic Pack 11. The Don Banks Collection, National Library of Australia, Canberra.

Banks, D. 1977. Interview with Barry Conyngham, 29 May. 'New Audience' concert recording, University of Melbourne.

Bate, M., dir. 2006. What The Future Sounded Like. Porthmeor Productions.

Blommers, W. 2001. Three Not Described Objects in Depot of Gemeentemuseum Den Haag, The Netherlands. http://nm-archives.electro-music.com/GDH/EMS-VCS1/ DocumentationVCS1DepotElectronica.html (accessed 13 December 2013).

Cary, T. 1968. Wanted: A National Workshop of Electronic Music. The Guardian, 13 August, 6.

Cary, T. 1969a. Promotional leaflet for the VCS3, November. EMS Archive, Cornwall.

Cary, T. 1969b. EMS Memo: Thoughts On Keyboard, 12 August. Collection of David Cockerell, London.

Cary, T. 1992. Illustrated Compendium of Musical Technology. London: Faber \& Faber. 
Cary, T. 2000. Email correspondence with Campbell Bickerstaffe, December.

Cary, T. 2003. Interview with Gabriella Smart, 3 September.

Cary, T. 2006. Transcript of interview with Andrew Ford for The Music Show, ABC Radio National, 11 February. www.abc.net.au/radionational/programs/musicshow/ tristram-cary/3337710 (accessed 14 March 2010).

Cary, T. n.d. [c. 2007]. The Sixties. Unpublished autobiographical notes. Collection of Jane Cary, Adelaide.

Casserley, L. 2015a. Interview with author, 20 January.

Casserley, L. 2015b. Email correspondence with author, 7 April.

Clark, G. 2016. What Were the British Earnings and Prices Then? (New Series). Measuring Worth. www.measuringworth. com/ukearncpi/ (accessed 29 October 2016).

Cleave, M. 1968. The Performer at the Bottom of Mr. Zinovieff's Garden. Evening Standard, 11 January, 7.

Cockerell, D. 1968. Handwritten instructions for Don Banks Music Box. Collection of Lawrence Casserley, Oxford.

Cockerell, D. 2000. Interview with Trevor Pinch, 30 August. Smithsonian Institution Analogue Music Synthesizer Oral History Collection NMAH.AC.0640.

Cockerell, D. 2010. Interview with author, 20 May.

Cockerell, D. 2014a. Email correspondence with author, 5 February.

Cockerell, D. 2014b. Email correspondence with author, 7 April.

Cockerell, D. 2015. Email correspondence with author, 21 May.

Cockerell, D. 2016. Interview with author, 18 April.

Crichton, R. 1968. Electronic Music (concert review). The Financial Times, 16 January.

Davies, H. 1968. Répertoire International des Musiques Electroacoustiques/International Electronic Music Catalog. Paris: Groupe de Recherches Musicales de l'O.R.T.F.; and Trumansburg, NY: Independent Electronic Music Center, Inc.

Davies, H. 2001. Gentle Fire: An Early Approach to Live Electronic Music. Leonardo Music Journal 11: 53-60.

Derbyshire, D. 1965. Letter to Hugh Davies, 23 November. Hugh Davies Archive.

Dowson, M. 2014. Email correspondence with author, 10 April.

Edgerton, D. 2007. The Shock of the Old. Oxford: Oxford University Press.

Ferguson, E. 1974. Toward a Discipline of the History of Technology. Technology and Culture 15: 13-30.

Gardner, J. 2016. Even Orpheus Needs a Synthi. TEMPO 70(276): 56-70.

Gilbert, A. 1968. SPNM Composers' Weekend. The Musical Times 109(1508): 946.

Hair, G. 2007. Don Banks, Australian Composer: Eleven Sketches. Amaroo, ACT: Southern Voices.

Helliwell, I. 2016. Tape Leaders: A Compendium of Early British Electronic Music Composers. Cambridge: Sound on Sound.

Hodgson, B. 2014. Interview with author, 3 July.

Jones, M. 1970. Electronic Music Written in Bed. Sydney Morning Herald, 25 March, 5.
Manning, P. 1985. Electronic and Computer Music. Oxford: Oxford University Press.

Nyman, M. 1971. The Gentle Fire. (concert review). The Musical Times 112(1538): 359.

Oram, D. 1963. Letter to Hugh Davies, 4 February. Hugh Davies Archive.

Patteson, T. 2016. Instruments for New Music: Sound, Technology and Modernism. Oakland, CA: University of California Press.

Pinch, T. and Bijker, W. 1984. The Social Construction of Facts and Artefacts: Or How the Sociology of Science and the Sociology of Technology Might Benefit Each Other. Social Studies of Science 14(3): 399-441.

Pinch, T. and Trocco, F. 1996. The Social Construction of the Early Music Synthesizer. In H.-J. Braun (ed.) Music and Technology in the Twentieth Century. Baltimore, MD: Johns Hopkins University Press. 2002.

Pinch, T. and Trocco, F. 2002. Analog Days: The Invention and Impact of the Moog Synthesizer. Cambridge, MA: Harvard University Press.

Powerhouse Museum. n.d. [Description of] H9953-13 Electronic Music Synthesiser, from Don Banks music studio. www.powerhousemuseum.com/collection/database/ ?irn=259174 (accessed 15 December 2011).

Moog Inc, R. A. 1969. Prices of Synthesizers and Single Function Instruments Currently Being Produced By R. A. Moog Inc. Trumansburg, NY: R. A. Moog Inc.

Sadie, S. 1968. New Music (concert review). The Musical Times 109(1501): 252.

Smart, G. 2009. Tristram Cary: Scenes from a Composer's Life. MMus thesis, University of Adelaide, Elder Conservatorium of Music. https://digital.library.adelaide.edu. $\mathrm{au} /$ dspace/bitstream/2440/69202/8/02whole.pdf (accessed 14 March 2014).

Théberge, P. 1997. Any Sound You Can Imagine: Making Music/Consuming Technology. Hanover, NH: Wesleyan University Press.

Ungeheuer, E. 2008. Imitative Instrumente und innovative Maschinen? Musikästhetische Orientiertungen der elektrischen Klangerzeugung. In Institut für Medienarchäologie (ed.) Zauberhafte Klangmaschine: Von der Sprechmaschine bis zur Soundkarte. Mainz, Germany: Schott.

Various Authors. 1968. Programme booklet for 'First London Concert of Electronic Music by British Composers', Queen Elizabeth Hall, London, 15 January.

Various Authors. 1969. Programme booklet for 'Electronic Music', Queen Elizabeth Hall, London, 10 February.

von Hippel, E. 1988. The Sources of Innovation. Oxford: Oxford University Press.

Willis, T. 1970. Critic Meets Putney, Makes a Friend, Takes Him to Church. Chicago Tribune, 14 June, F2.

Zinovieff, P. 1969. The Special Case of Inspirational Computer Music Scores. London Magazine 9(4): 165-76.

Zinovieff, P. 2000. Interview with Trevor Pinch, 29 August. Smithsonian Institution Analogue Music Synthesizer Oral History Collection NMAH.AC.0640.

Zinovieff, P. 2010. Interview with author, 22 March.

Zinovieff, P. 2016. Interview with author, 9 April. 